LINGUA, Vol. 16, No. 2, September 2019

p ISSN: 1979 9411; e ISSN: 2442 238X

Http://lingua.soloclcs.org; Email: presslingua@gmail.com

Center of Language and Cultural Studies, Surakarta, Indonesia

Mutlak, Arifuddin \& Yusra, Kamaludin. 2019. Penamaan Diri Masyarakat Bima

sebagai Sapaan Hormat kepada Orang yang Dituakan:

Kajian Fonologis dan Kontribusinya dengan Pengajaran di SMP.

Lingua (2019), 16(2): 235-246. Http://doi.org/10.30957/lingua.v16i2.270.

\title{
Penamaan Diri Masyarakat Bima Sebagai Sapaan Hormat Kepada Orang yang Dituakan: \\ Kajian Fonologis dan Kontribusinya dengan Pengajaran di SMP
}

\author{
Mutlak, Arifuddin \& Kamaluddin Yusra \\ Program Studi Magister Pendidikan Bahasa Indonesia, \\ Universitas Mataram \\ Jl. Majapahit No. 62 Mataram 83125 \\ Correspoding email: mutlakbtnbhp@gmail.com. \\ arifuddin@unram.ac.id \& kyusra@unram.ac.id
}

\begin{abstract}
The study addresses honorific greeting delivered by Bima community using Donggo dialect to greet others. Specifically, the honorific address is used to greet elders using specific names that the local culturally indicates high respocet and honor. This study used qualitative approach and rooted on the sociolinguistics as the foundation of the understanding of the socio-cultural perspectives. The site of the study was Mbawa village, Donggo ditrict, Bima Regency. A number of local community consisting of 50 adult men and 50 adult women were observed as the informants of the study. Data were collected using direct observation and interview. Results show that Bima community perceive greeting is socially embedded in the culture to raise honor to others, elders, mates and the younger. The culture system in the Bima tradition is using modified self-naming to put respect and honor. The system of honorific address socially expresses politeness and religious values that root from the Islamic teaching. As the address system embeds cultural values that in sociolinguistic refers to politeness this study adversely contributes teaching language for secondary school students, implying that self-naming to express honorific address is contributable to school curriculum.
\end{abstract}

Keyword: self-naming, honor greetings, address, politeness.

\section{PENDAHULUAN}

Bahasa adalah sistem lambang bunyi yang dipakai oleh suatu masyarakat untuk berinteraksi. Bahasa merupakan ciri khas suatu daerah, bangsa dan negara. Sebagai alat komunikasi bahasa memiliki peran penting yang dapat mempersatukan antara masyarakat yang satu dengan masyarakat yang lain dalam kehidupan bermasyarakat, berbangsa dan bernegara. Termasuk salah satu ciri khas dalam sebuah budaya adalah sapaan penghormatan dalam masyarakat Bima dialek Donggo kepada orang yang lebih tua.

Sapaan penghormatan dalam bahasa bima pada umumnya dan dielek Donggo pada khususnya merupakan warisan budaya leluhur dari sejak zaman kesultanan Bima yang sudah secara turun-temurun. Ketika seseorang berbicara atau berkomunikasi dengan orang lain, maka secara langsung penggunaan kata sapaan penghormatan itu digunakan untuk menghormati yang lebih tua. Apakah seseorang itu memiliki status 
sosial, jabatan dan gelar maupun tidak memiliki status sosial/jabatan tersebut, mereka selalu menggunakan bahasa atau sapaan penghormatan.

Bahasa yang dimiliki oleh suatu daerah mempunyai ciri khas tersendiri. Ciri khas yang dimaksud dapat berupa sistem bunyi, sitem pembentukan kata, sistem pembentukan kalimat dan sistem-sistem lainnya. Ciri khas tersebut terdapat pula pada bahasa Bima yang digunakan oleh penutur bahasa Bima. Terkait dengan ciri khas dengan bahasa Bima, salah satunya adalah penamaan diri masyarakat Bima sebagai sapaan penghormatan kepada orang yang dituakan untuk berkomunikasi dan berinteraksi dengan sesama penutur bahasa bima dalam kehidupan bermasyarakat.

Penamaan diri sebagai sapaan penghormatan merupakan pemberian nama lain yang mirip dengan nama yang sebenarnya kepada orang yang dituakan untuk menghargai terhadap lawan tutur yang lebih tua. Nama sapaan tersebut memang sudah dibentuk oleh lingkungannya yang secara turun-temurun keberadaannya dalam komunikasi nonformal. Hal ini menyebabkan mitra tutur baik dari daerah setempat maupun dari daerah lain yang ada di Lingkungan wilayah Bima pada umumnya. Ketika sesorang berkunjung atau berkomunikasi antara seseorang dengan orang lain, maka terjadi komunikasi tindak tutur yang melibatkan sapaan penghormatan tersebut. Namanama diri yang digunakan sebagai sapaan penghormatan dalam bahasa Bima seperti; Abdul Kadir menjadi (sapaan penghormatan kedo), Abdullah menjadi (sapaan penghormatan Dole), Nurdin menjadi (sapaan penghormatan Deo), Syahbuddin menjadi (sapaan penghormatan Bedo), Imran menjadi (sapaan penghormatan Rao), Halimah menjadi (sapaan penghormatan Lomi/lamu), Nurhayati menjadi (sapaan penghormatan Tau), Aminah menjadi (sapaan penghormatan Mene), Ramlah menjadi (sapaan penghormatan Lau), Siti Aisyah menjadi (sapaan penghormatan Sita/Sei) dan lain-lain.

Muncul penamaan diri dalam masyarakat bima sebagai sapaan hormat kepada seseorang yang lebih tua umurnya. Dengan demikian menunjukkan keunikan tersendiri dalam bahasa Bima. Penamaan diri itu berupa perubahan bunyi atau perubahan bentuk pada nama panggilan sebenarnya ketika berinteraksi sesama penutur bahasa bima dialek Donggo.

Masalah yang akan dibahas dalam penelitian ini berkaitan dengan kajian Varian Sapaan hormat pada orang yang dituakan dalam masyarakat Bima dari segi Sosiolingustik dan kontrisinya dengan pembelajaran bahasa sebagai berikut.

a. Bagaimanakah varian secara geografis Penamaan Diri Masyarakat Bima sebagai Sapaan hormat pada orang yang dituakan?

b. Faktor apa sajakah yang mempengaruhi fungsi Penamaan Diri Masyarakat Bima pada orang yang dituakan?

c. Bagaimanakah kontribusinya Penamaan Diri Masyarakat Bima pada orang yang dituakan dengan pembelajaran bahasa Indonesia di SMP?

\section{LANDASAN TEORI}

Teori ini memuat konsep dan hal-hal konseptual lainnya yang memilki hubungan dengan variabel penelitian.

Berdasarkan Kamus Besar Bahasa Indonesia (KBBI, 2008:1040), pelesetan diartikan membuat sesuatu diluar yang sebenarnya. Sebagaimana pengertian pelesetan yang telah 
dikemukakan di KBBI (2008:1040), peneliti memberikan pengertian terkait dengan pelesetan dalam bahasa Indonesia yaitu bentuk deviasi bunyi dari yang sebenarnya.

\subsection{Nama sapaan/panggilan}

Sebagaimana pengertian yang tercantum pada Kamus Besar Bahasa Indonesia (KBBI, 2008:950), nama sapaan atau panggilan merupakan panggilan nama yang digunakan dalam penyapaan. Oleh karena itu, dapat dikatakan bahwa nama panggilan itu sama dengan sapaan. Berikut akan dikemukakan beberapa teori sapaan:

\section{a. Teori sapaan menurut Fasold}

Bentuk sapaan menurut Fasold (1990), kata-kata yang penutur gunakan untuk menandakan atau menunjuk orang yang diajak bicara ketika mereka bicara dengannya (dalam Wajdi, 2011:3). Dalam beberapa bahasa, ada dua jenis bentuk sapaan yang utama yaitu nama dan kata sapaan. Bentuk sapaan adalah bagian dari sistem makna yang lengkap yang diperlakukan berkenaan dengan hubungan sosial. Bentuk sapaan digunakan ketika seorang penutur sudah mendapat perhatian pendengar, panggilan adalah untuk menarik perhatian.

\section{b. Sapaan menurut Brown dan Gilman}

Brown dan Gilman (1960) mengemukakan bahwa kata sapaan merujuk pada kata ganti yang digunakan untuk menyapa orang kedua. Penelitian yang dilakukan terhadap penggunaan bahasa-bahasa Eropa, seperti bahasa perancis, bahasa Jerman, bahasa Italia dan bahasa Spanyol. Brown dan Gilman menemukan bahwa pemilihan kata ganti orang kedua yang digunakan pembicara kepada lawan bicaranya yang dipengaruhi oleh dua faktor, yakni kekuasaan (power) dan solidaritas (solidarity) (Fasold, 1994:3, dalam Rahmania, 2009:19).

\section{c. Teori sapaan menurut Tripp}

Tripp melakukan penelitian terhadap kata sapaan yang digunakan oleh penutur bahasa Inggris. Adapun kata sapaan yang digunakan merujuk pada kata ganti orang kedua. Berdasarkan penelitian tersebut, Tripp menemukan bahwa terdapat dua kaidah yang harus ada dalam penggunaan sapaan yaitu kaidah alternasi dan kaidah kookurensi (dalam Rahmania, 2009:21). Tripp mengemukakan bahwa kaidah alternasi merupakan kaidah yang berkaitan dengan cara menyapa. Kaidah ini berhubungan dengan digunakannya suatu bentuk kata sapaan berdasarkan faktor-faktor yang mempengaruhi. Adapun faktor-faktor yang dimaksud adalah sebagai berikut.

\section{1) Situasi yang ditandai oleh status.}

Situasi yang ditandai status merujuk pada latar atau tempat status dan gaya bicara ditetapkan dengan jelas, seperti di ruang perkuliahan, dan ruang pertemuan lainnya. Dengan latar tersebut, kata sapaan tiap orang diambil dari identitas sosialnya, seperti pak Hakim dan Pak ketua. 


\section{2) Pangkat}

Pangkat merujuk pada tingkatan dalam suatu kelompok kerja. Tingkatan tersebut merujuk pada perbedaan status seperti guru dan murid.

\section{3) Perangkat identitas}

Perangkat identitas merujuk pada gelar dalam pekerjaan atau gelar penghormatan. Orang yang memiliki gelar tersebut dapat disapa dengan menyebutkan gelarnya saja, seperti pak dokter dan pak Haji.

\section{d. Teori sapaan menurut Kridalaksana}

Kata sapaan merujuk pada kata atau ungkapan yang dipakai untuk menyebut dan memanggil para pelaku dalam suatu peristiwa bahasa, sedangkan para pelaku yang dimaksud merujuk pada pembicara, serta orang yang dibicarakan (Kridalaksana, 1982:14). Kridalaksana menggolongkan kata sapaan menjadi beberapa bagian sebagai berikut.

a. Kata ganti, seperti aku, kamu dan dia

b. Nama diri, Seperti Galih dan Ratna

c. Istilah kekerabatan, seperti bapak dan ibu

d. Gelar dan pangkat, seperti dokter dan guru

e. Bentuk pe $+\mathrm{V}$ (verbal) atau kata pelaku, seprti kata penonton dan pendengar

f. Bentuk N (nomina) $+\mathrm{ku}$, seperti kekasihku dan Tuhanku

g. Kata deiksis atau petunjuk, seperti sini dan situ

h. Kata benda lain, seperti tuan dan nyonya.

Masih menurut Kridalaksan (1982:1993), jenis kata sapaan yang nampaknya paling banyak digunakan dalam bahasa indonesia adalah istilah kekerabatan. Status dapat diartikan sebagai posisi sosial lawan bicara terhadap pembicara dan dapat pula diartikan sebagai usia. Adapun faktor fungsi adalah jenis kegiatan atau jawaban lawan bicara dalam suatu peristiwa bahasa atau pembicaraan. Dua faktor tersebut dapat dilihat pada tabel status dan fungsi mempengaruhi kata sapaan terhadap lawan bicara dalam bahasa Indonesia menurut Kridalaksana.

Tabel 1.

Status dan fungsi kata sapaan bahasa Indonesia

\begin{tabular}{|l|c|c|c|}
\hline \multicolumn{2}{|c|}{ Status } & \multicolumn{2}{c|}{ Fungsi } \\
\cline { 1 - 2 } Lebih tinggi & Bapak, $i b u, d s b$ & Kata pelaku & Pembaca, dsb \\
\cline { 1 - 2 } Sama & Saudara, $a$ anda, $d s b$ & Pangkat/gelar & Dokter, guru, $d s b$ \\
\cline { 1 - 2 } Lebih rendah & Saudara, $a d i k, d s b$ & & \\
\hline
\end{tabular}

Konsep yang berkaitan dengan pelesetan nama panggilan atau nama sapaan penghormatan yang telah dipaparkan, maka peneliti pun menyimpulkan bahwa pelesetan nama panggilan adalah nama sapaan penghormatan yang mengalami deviasi dari nama sebenarnya. 


\subsection{Fonologi}

Beberapa teori yang berkaitan dengan fonologi akan dipaparkan sebagai berikutini. Jacobson (1941) memperkenalkan teori structural sejagat. Teori ini mencoba menerangkan pemerolehan fonologi berdasarkan jagat-jagat linguistik (linguistik universal), yaitu hukum-hukum struktural yang melandasi tiap-tiap bahasa dan seterusnya menghubungkan dengan afasia dan proses penyembuhan afasia. Selain itu teori ini didasarkan pada sistem analisis fitur distignif dan teori ini menganggap bahwa pemerolehan dan perkembangan fonologi anak-anak adalah suatu proses yang kreatif (dalam Simajuntak, 1990:25).

Menurut KBBI (2008:396), fonologi adalah bidang linguistik yang mempelajari, menganalisis, dan membicarakan runtutan bunyi-bunyi bahasa.

Muslich (2010:1-2) mengemukakan kajian mendalam tentang bunyi-bunyi ujar ini diselidiki oleh cabang linguistik yang disebut fonologi. Fonologi mempunyai dua cabang kajian, yaitu (1) fonetik dan (2) fonemik. Verhar (2010:10) mengatakan bahwa ilmu fonologi meneliti bunyi bahasa tertentu menurut fungsinya. Sedangkan Siswono, dkk. (2011:55) mengatakan bahwa fonologi adalah ilmu yang mempelajari bunyi-bunyi bahasa (fonem-fonem). Berdasarkan beberapa pendapat tentang fonologi, peneliti menyimpulkan bahwa fonologi merupakan ilmu yang mempelajari tentang fungsi ragam bunyi-bunyi bahasa.

\section{METODE}

Penelitian ini bersifat deskriptif kualitatif karena itu metode yang digunakan adalah metode deskriptif. Djajasudarma (1993:38) mengatakan bahwa metode deskriptif adalah metode yang bertujuan untuk membuat gambaran lukisan secara sistematis faktual dan akurat mengenai data, sifat serta hubungan fenomena-fenomena yang diteliti.

Penelitian ini termasuk jenis penelitian deskriptif kualitatif yaitu jenis penelitian yang berupaya untuk menggambarkan pemecahan masalah tanpa melalui prosedur statistik atau bentuk hitungan. Teknik yang digunakan dalam penyediaan data penelitian ini adalah 1) metode catat yaitu peneliti mencatat nama-nama diri sebagai sapaan penghormatan dalam bahasa Bima. 2) metode cakap (wawancara), peneliti menggunakan teknik dasar dalam metode cakap yaitu teknik pancing, yang mana peneliti memancing informan untuk berbicara. Selain itu peneliti menggunakan teknik lanjutan cakap semuka, karena peneliti melakukan percakapan langsung dengan cara berhadapan langsung dengan informannya. Peneliti akan mengamati dan membedah hasil dari pengumpulan data dengan menggunakan metode padan ekstralingual, yang mana peneliti menghubungbandingkan bahasa dengan hal-hal di luar bahasa, misalnya konteks sosial pemakaian bahasa berdasarkan umur, jenis kelamin, dan kelas sosial. Penelitian ini menggunakan teknik penyajian dengan katakata biasa, termasuk penggunaan terminologi yang bersifat teknis (Sudaryanto, 1993:145).

\section{HASIL DAN PEMBAHASAN}

Penelitian tentang pelesetan nama panggilan sebagai sapaan hormat kepada orang yang dituakan dalam masyarakat Bima dialek Donggo belum pernah dilakukan. 
Nama panggilan sebagai sapaan dapat diartikan sebagai panggilan nama yang digunakan dalam menyebutkan atau menyapa nama seseorang.

Penelitian ini dilaksanakan di Desa Mbawa Kecamatan Donggo Kabupaten Bima Nusa Tenggara Barat (NTB). Dilihat dari letak geografisnya bentuk wilayah Desa Mbawa Kecamatan Donggo termasuk daerah dataran tinggi. Jarak tempuh dari kota Kabupaten dengan Desa Mbawa Kecamatan Donggo $15 \mathrm{~km}$ dan jarak tempuh sepeempat jam. Jumlah penduduk di Desa Mbawa Kecamatan Donggo kurang lebih 5000 jiwa, yang terdidi dari anak-anak, remaja, dewasa dan orang tua. Sebagian besar Masyarakat Desa Mbawa Kecamatan Donggo berprofesi sebagai petani, ada juga yang menjadi PNS, TNI, POLRI, dan Pedagang. Bahasa yang yang digunakan Masyarakat Desa Mbawa Kecamatan Donggo adalah bahasa Bima dalek Donggo. Ketika berinteraksi atau berkomunikasi masyarakat menggunakan sapaan penghormatan antara yang muda dan yang lebih tua untuk menghormati dan menghargai. Hal tersebut menunjukkan adanya keragaman penutur bahasa yang akan memunculkan variasi bahasa yang digunakan dalam berinteraksi antara satu sama lain. Keanekaragaman tersebut meliputi jenis kelamin, umur, dan status sosial penutur bahasa khususnya bahasa Bima dialek Donggo.

Bentuk-bentuk variasi bahasa yang digunakan dalam interaksi masyarakat Desa Mbawa Kecamatan Donggo Kabupaten Bima adalah sebagai berikut:

\subsection{Variasi bahasa dari segi penutur}

Idiolek anak, remaja, dewasa dan orang tua memiliki idiolek yang bervariasi. Ditemukan sapaan penghormatan nama diri seperti Arsyad menjai Seo, Arman menjadi Moa, Usman menjadi Moa, Ibrahi menjadi Boa dan lain-lain. Bentuk varian sapaan penghormatan yang lain dalam bahasa masyarakat Desa Mbawa kecamatan Donggo yaitu:

- Mada (saya)

- Ita (kamu)

Kata mada dan ita biasa digunakan oleh seseorang yang lebih muda umurnya ketika berkomunikasi dengan seseorang yang lebih tua sebagai bentuk menghormati atau menghargai dalam berinteraksi sosial.

- Nggomi (kamu)

- Nahu (saya)

Kata nggomi dan nahu biasa digunakan oleh seseorang yang lebih tua kepada yang lebih muda dan antar sebaya.

Terkait dengan penyapaan, beberapa penelitian tentang kata sapaan pernah dilakukan diantaranya, Jafar (2002), Rahmania (2009), Rusbiyantoro (2011). Rahmania (2009) melakukan penelitian tentang kata sapaan dalam masyarakat Baduy. Dalam penelitian itu, Rahmania memaparkan jenis-jenis kata kata sapaan yang dipakai oleh masyarakat Baduy. Selain itu, penelitian Rahmania juga membahas faktor-faktor apa saja yang mempengaruhi digunakan suatu jenis kata sapaan di Baduy sehingga dapat diketahui sistim sapaan masyarakat Baduy. Penelitian tersebut melalui tiga tahapan, yakni (1) tahap penyediaan data, (2) tahap analisis data, (3) tahap penyajian hasil 
analisis data. Penelitian tersebut merupakan penelitian kualitatif dengan desain deskriptif.

Adapun Rusbiyantoro (2011) melakukan penelitian tentang penggunaan kata sapaan dalam bahasa Melayu Kutai. Bahasa Melayu Kutai merupakan bahasa yang paling banyak digunakan di Kalimantan Timur, terutama di wilayah bekas kerajaan Kutai Kartanegara. Adapun metode yang digunakan adalah mulai dari penyediaan data dengan metode wawancara, observasi, kuisioner/angket, dan analisis data dengan metode padan. Berdasarkan hasil penelitian Rusbiyantoro, terdapat sejumlah bentuk sapaan dalam bahasa Melayu Kutai, yaitu sapaan yang berkaitan dengan kekerabatan, pronominal persona, nama diri dan gelar bangsawan. Pilihan bentuk-bentuk sapaan di dalam komunikasi masyarakat Kutai ditentukan oleh beberapa faktor yang berkaitan dengan situasi, usia dan jenis kelamin, keintiman dan status sosial. Dari keseluruhan sapaan yang ditemukan tidak ada sapaan yang bersifat absolut, tetapi dapat berubah dipengaruhi oleh fakstor-faktor sosial.

Khususnya yang berkaitan dengan julukan, menurut Rusbiyantoro (2011:14), penggunaan kata sapaan berupa julukan yang ditemui dalam bahasa Melayu Kutai adalah nama diri mitra tutur selain nama yang telah ada. Sapaan julukan jenis ini biasanya digunakan antara penutur dan mitra tutur yang memiliki hubungan sangat dekat atau akrab dalam situasi informal. Sapaan ini yang umum digunakan oleh masyarakat Kutai adalah nama sapaan sejak kecil dan berdasarkan pekerjaan atau kegiatan yang dilakukan. Beberapa penelitian yang telah dilakukan, penelitian nama sapaan hormat yang dikaji secara linguistik selama ini belum tersentuh. Oleh karena itu, peneliti tertarik mengkaji nama panggilan sapaan hormat kepada orang yang dituakan dalam bahasa Bima dialek Donggo berdasarkan kajian fonologis dan Kontribusinya dengan pengajaran di SMP.

Tabel 2 menunjukkan Penamaan Diri Masyarakat Bima sebagai Sapaan hormat berdasarkan umur/usia.

Tabel 2. Penamaan Diri rasa hormat masyarakat Bima

\begin{tabular}{|c|c|c|c|c|}
\hline \multirow{2}{*}{ No } & \multirow{2}{*}{$\begin{array}{c}\text { Nama } \\
\text { Panggilan asli }\end{array}$} & \multicolumn{3}{|c|}{ Nama panggilan/sapaan Penghormatan } \\
\hline & & Muda & sebaya & Tua \\
\hline 1 & Ismail & Mo,i & Sma,i & Sma,i \\
\hline 2 & Usman & Moa & Usma & Usuma \\
\hline 3 & Halimah & Lomi/Lamu & Halima & Halima \\
\hline 4 & Aminah & Mene & Mina & Mina \\
\hline 5 & Syahbuddin & Bedo & Budi & Budi \\
\hline 6 & Arman & Moa & Arama & Arama \\
\hline 7 & Abdullah & Dole & Dula & Dula \\
\hline 8 & Ibrahim & Boa & Brahi & Brahi \\
\hline 9 & Nurhayati & Tau & Haya & Haya \\
\hline 10 & Aisyah & Sei & Aisya & Aisya \\
\hline
\end{tabular}




\subsection{Strata Sapaan}

Berdasarkan nama-nama tersebut di atas, kebiasaan orang Bima menyapa atau memanggil nama seseorang berdasarkan status umur/usia untuk membedakan rasa hormatnya.

Contoh percakapan berikut!

A : Bune habata Ama (bagaimana kabarnya Bapak)

B : Tahojampa ake, aurawi hera dohomu (baik-baik saja, bagaimana kabar iparmu)

A : Taho sara,ampa hera ro ina dohoka (baik-baik saja ipar dan Ibu semuanya)

B : Syukurde, edejampa diraho (Syukurlah, itu yang diharapkan)

Selanjutnya, berdasarkan sapaan dan stratanya, peneliti mengemukakan beberapa contoh sapaan sapaan yang ditemukan dalam penelitian di masyarakat.

1) Ismail apabila yang menyapanya adalah masih muda, maka biasa dipanggil “ $\mathbf{M o , i}$. Jika yang memanggil adalah umurnya sebaya, maupun lebih tua darinya, maka biasanya dipanggil "Sma,i". Tidak hanya itu, apabila seseorang tersebut memiliki status sosial atau jabatan, maka yang sebaya pun akan memanggil dengan sapaan penghormatan "Pak Mo,i", kemudian yang lebih tua umurnya biasa menyapanya dengan sapaan “ Pak Ismai”.

2) Usman apabila yang menyapanya lebih muda, maka biasa dipanggil Moa, Jika yang menyapanya lebih tua darinya, maka biasa dipanggil Usuma. Jika seseorang tersebut memiliki status soasial, jabatan, pangkat atau kedudukan baik yang muda, maupun sebaya, biasanya menyapa dengan "pak Moa”. Sedangkan yang lebih tua memanggil dengan sapaan "Pak usuma".

3) Halimah apabila yang menyapanya lebih muda dari segi usianya, maka biasa dipanggil Lomi/lamu, Jika yang menyapanya sebaya atau lebih tua darinya, maka biasa dipanggil Halima. Apabila seseorang tersebut memiliki status soasial, jabatan, pangkat atau kedudukan yang lebih muda akan menyapanya dengan sapaan "BuLomi/Lamu", Sedangkan yang sebaya, maupun yang lebih tua biasanya menyapa dengan “Bu Halima”.

4) Aminah apabila yang menyapanya lebih muda dari segi usianya, maka biasa dipanggil Mene, Jika yang menyapanya sebaya atau lebih tua darinya, maka biasa dipanggil Mina. Jika seseorang tersebut memiliki status soasial, jabatan, pangkat atau kedudukan baik yang muda, biasanya menyapa dengan sapaan "Bu Mene". Sedangkan yang sebaya maupun yang lebih tua akan memanggil dengan sapaan “ Bu Mina”.

5) Syahbuddin apabila yang menyapanya lebih muda dari segi usianya, maka biasa dipanggil Bedo, Jika yang menyapanya sebaya atau lebih tua darinya, maka biasa dipanggil Budi. Jika seseorang tersebut memiliki status soasial, jabatan, pangkat 
atau kedudukan yang muda akan menyapanya dengan sapaan "Pak Bedo.", Sedamgkan yang sebaya, maupun yang lebih tua biasanya menyapa dengan "pak Budi”.

6) Arman apabila yang menyapanya lebih muda dari segi usianya, maka biasa dipanggil “Moa”, Jika yang menyapanya sebaya atau lebih tua darinya, maka biasa dipanggil "Arama". Apabila seseorang tersebut memiliki status soasial, jabatan, pangkat atau kedudukan yang lebih muda biasa dipanggil "Pak Moa", sedangkan yang menyapanya sebaya maupun yang lebih tua biasanya menyapa dengan "pak Arama”.

7) Abdullah apabila yang menyapanya lebih muda dari segi usianya, maka biasa dipanggil "Dole", Jika yang menyapanya sebaya atau lebih tua darinya, maka biasa dipanggil "Dula". Apabila seseorang tersebut memiliki status sosial, jabatan, pangkat atau kedudukan yang lebih muda biasa dipanggil "Pak Dole", sedangkan yang menyapanya sebaya maupun lebih tua biasanya menyapa dengan "pak Dola".

8) Ibrahim apabila yang menyapanya lebih muda dari segi usianya, maka biasa dipanggil "Boa", Jika yang menyapanya sebaya atau lebih tua darinya, maka biasa dipanggil "Brahi". Jika seseorang tersebut memiliki status soasial, jabatan, pangkat atau kedudukan yang lebih muda biasa dipanggil "Pak Boa", sedangkan yang menyapanya sebaya maupun lebih tua biasanya menyapa dengan "pak Brahi'.

9) Nurhayati apabila yang menyapanya lebih muda dari segi usianya, maka biasa dipanggil "Tau", Jika yang menyapanya sebaya atau lebih tua darinya, maka biasa dipanggil "Haya”. Jika seseorang tersebut memiliki status soasial, jabatan, pangkat atau kedudukan yang muda, bianya memanggil denagan sapaan "Bu $\boldsymbol{T a}$ " Jika yang menyapanya sebaya maupun lebih tua, biasanya menyapa dengan sapaan " $\boldsymbol{b u}$ Haya”.

10) Aisyah apabila yang menyapanya lebih muda dari segi usianya, maka biasa dipanggil "Sei". Jika yang menyapanya sebaya atau lebih tua darinya, maka biasa dipanggil "Aisya". Jika seseorang tersebut memiliki status soasial, jabatan, pangkat atau kedudukan, yang muda bianya memanggil denagan sapaan "Bu sei”. Apabila yang menyapanya sebaya maupun yang lebih tua biasanya menyapa dengan sapaan "Bu Aisya”.

Di Samping sapaan penghormatan nama diri seperti penjelasan di atas, bahasa Bima juga mempunyai kultur budaya sistim sapaan kekerabatan dalam lingkungan keluarga. Periksa Tabel 3. 
LINGUA, Vol. 16, No. 2, September 2019

p ISSN: 1979 9411; e ISSN: 2442 238X

Http://lingua.soloclcs.org; Email: presslingua@gmail.com

Center of Language and Cultural Studies, Surakarta, Indonesia

Mutlak, Arifuddin \& Yusra, Kamaludin. 2019. Penamaan Diri Masyarakat Bima sebagai Sapaan Hormat kepada Orang yang Dituakan:

Kajian Fonologis dan Kontribusinya dengan Pengajaran di SMP.

Lingua (2019), 16(2): 235-246. Http://doi.org/10.30957/lingua.v16i2.270.

Tabel 3. Budaya sistem sapaan masyarakat Bima

\begin{tabular}{|l|l|l|}
\hline No & Nama sapaan dalam Bahasa Bima & Arti dalam bahasa Indonesia \\
\hline 1 & Ama, Dae, Muma, Uba & Bapak/ ayah \\
\hline 2 & Ina & Ibu, mama \\
\hline 3 & Sa,e, ari & Kakak, adik \\
\hline 4 & Ori, manca & Paman, bibi \\
\hline 5 & Amania & Saudara laki-laki \\
\hline 6 & Amancawa & Saudara perempuan \\
\hline 7 & Ompu & kakek \\
\hline 8 & Wa,i & nenek \\
\hline 9 & Hera & Ipar \\
\hline 10 & Rido & mantu \\
\hline
\end{tabular}

Temuan di atas menunjukkan dua hal: Faktor yang mempengaruhi fungsi penamaan diri Masyarakat Bima, dan kontribusinya terhadap pembelajaran bahasa Indonesia di SMP. Faktor yang mempengaruhi penamaan diri dalam masyarakat Bima, khususya masyarakat Desa Mbawa kecamatan Donggo adalah sebagai bentuk tata krama, sopan santun, saling menghormati dan menghargai ketika masyarakat berinteraksi antara satu sama lain. Adapun, kontribusi penamaan diri masyarakat Bima dengan pembelajaran bahasa di SMP ialah:

- Para pelajar (siswa) paham dan mengenal betapa pentingnya pembelajaran tentang materi muatan lokal bahasa Bima untuk memperkaya budaya Nasional.

- Untuk mengenal berbagai ragam bahasa yaitu ragam bahasa baku dan non baku termasuk sapaan nama diri masyarakat Bima.

- Mengetahui dan mengenal bentuk tata krama, sopan santun, menghormati dan menghargai dalam berkomunikasi antara anak-anak dengan orang tua, umur sebaya maupun antara yang muda dengan orang tua, maupun sebaliknya.

\section{SIMPULAN}

Hasil penelitian ini secara umum dapat disimpulkan bahwa penamaan diri masyarakat Bima sebagai sapaan hormat kepada orang yang dituakan memiliki sistem budaya sapaan dan strata sapaan terkait dengan status, usia, dan posisi yang disapa. Masyarakat Bima tidak hanya mengenal nama-nama orang sebagai sapaan penghomatan, tetapi juga mempunyai kultur budaya sapaan dalam lingkungan keluarga. Secara khusus, masyarakat Bima ketika berbicara dengan orang lain yang usianya lebih tua, maka selalu menggunakan sapaan penghormatan. Nama-nama orang dalam sapaan bahasa Bima tidak mengenal huruf konsonan akhir, dan identik dengan huruf akhir vokal yaitu a, i, u, e, o, misalnya Usman menjadi moa, Arman menjadi moa, Ibrahimmenjadi boa, Ismail menjadi Mo, $i$, Aisyah menjadi Sei, Halimah menjadi Lomi, Nurhayati menjadi Tau, Abdullah menjadi Dole, Aminah menjadi Mene, dan Syahbuddin menjadi Bedo dan lain sebagainya. Sapaan-sapaan tersebut di atas memiliki nilai rasa kedekatan dan kekeluargaan yang mendalam apabila dalam tutur sapa bahasa Bima, sesorang menggunakan bahasa sapaan tersebut, baik dalam lingkup keluarga 
LINGUA, Vol. 16, No. 2, September 2019

p ISSN: 1979 9411; e ISSN: 2442 238X

Http://lingua.soloclcs.org; Email: presslingua@gmail.com

Center of Language and Cultural Studies, Surakarta, Indonesia

Mutlak, Arifuddin \& Yusra, Kamaludin. 2019. Penamaan Diri Masyarakat Bima sebagai Sapaan Hormat kepada Orang yang Dituakan:

Kajian Fonologis dan Kontribusinya dengan Pengajaran di SMP.

Lingua (2019), 16(2): 235-246. Http://doi.org/10.30957/lingua.v16i2.270.

maupun masyarakat Bima pada umumnya. Pelesetan nama sapaan/panggilan hormat dalam bahasa Bima dapat digunakan sebagai bahan ajar dalam pengajaran bahasa, baik bahasa daerah maupun bahasa Indonesia formal. Pemanfaatan ini merupakan bentuk dari kontribusi antara kajian sosiolingusitik pelesetan nama sapaan yang disajikan dengan pengajaran bahasa. Materi pengajaran berupa sapaan/ plesetan nama panggilan dapat disajikan dengan konsep materi dan aplikasinya dalam bentuk contoh yang dapat diterapkan dalam materi kebahasaan.

\section{DAFTAR PUSTAKA}

Chaer, Abdul \& Agustina Leoni. 2014. Sosiolinguistik. Jakarta: PT. Rineka Cipta. Chaer, Abdul \& Agustina Leoni. 2007. Linguistik Umum. Jakarta: Rineka Cipta.

Chaer, Abdul \& Agustina Leoni.2009. Fonologi Bahasa Indonesia. Jakarta: Rineka Cipta.

Chaer, Abdul \& Agustina Leoni. 2015. Psikolinguistik. Jakarta: PT. Rineka Cipta.

Departemen Pendidikan Nasional. 2008. Kamus Besar Pusat Bahasa edisi keempat. Jakarta: PT Gramedia Pustaka Utama.

Emzir. 2010. Metodologi Penelitian Pendidikan Kuantitatif dan Kualitatif. Jakarta: Rajawali Press.

Erwin, dkk. 2013. Penggunaan Bahasa Mbojo di Lingkungan Masyarakat Bima: Sebuah Kajian Variasi Bahasa. http://media. Neliti. Com//20685. 18 Desember 2018.

Indah, Novianti Marina. 2017. Penggunaan Pelesetan Nama Panggilan dalam Masyarakat Sasak dan Relevansinya dengan Pembelajaran di SMA. Mataram: Universitas Mataram.

Jafar, Syamsinah. 2002. Sistem Sapaan Pronomina Persona Bahasa Bima: Kajian Makna Penghormatan dan Solidaritas. Fakultas Keguruan dan Ilmu Pendidikan Universitas Mataram.

Kridalaksan, Harimukti. 2010. Pembentukan kata dalam Bahasa Indonesia. Jakarta: PT Gramedia.

Kridalaksan, Harimukti. 1982. Fungsi Bahasa dan Sikap Bahasa. Flores: Nusa Indah.

Mahsun. 2007. Metode Penelitian Bahasa: Tahapan Strategi, Metode dan Tekniknya. Jakarta: PT.Grafindo.

Mahsun. .2010. Pembentukan kata dalam Bahasa Indonesia. Jakarta: PT.Grafindo.

Mahsun. .2017. Metode Penelitian Bahasa. Depok: PT Rajagrafindo Persada.

Marsono. 2008. Fonetik. Yogyakarta: Gajah Mada University Press.

Muslim, Nurcholis. dkk. 2015. Kamus Mbojo Indonesia. Mataram: Kantor Bahasa Pendidikan dan Kebudayaan. Propinsi NTB. Badan Pengembangan dan Pembinaan Bahasa Kementrian

Moleong, lexi J. 2007. Metodologi Penelitian Kualitatif. Bandung: PT. Remaja Rosdakarya.

Nurmawati. 2012. Plesetan Nama Panggilan dalam Bahasa Sasak. Universitas Mataram.

Nugraheni, Yestisia Krisinta 2008. The Study of Word Play (Pelesetan) in CAPEK (Catatan Pelesetan Pelik) Column. Semarang: Universitas Diponegoro. 
LINGUA, Vol. 16, No. 2, September 2019

p ISSN: 1979 9411; e ISSN: 2442 238X

Http://lingua.soloclcs.org; Email: presslingua@gmail.com

Center of Language and Cultural Studies, Surakarta, Indonesia

Mutlak, Arifuddin \& Yusra, Kamaludin. 2019. Penamaan Diri Masyarakat Bima sebagai Sapaan Hormat kepada Orang yang Dituakan:

Kajian Fonologis dan Kontribusinya dengan Pengajaran di SMP. Lingua (2019), 16(2): 235-246. Http://doi.org/10.30957/lingua.v16i2.270.

Nursyahidah. 2018. Representasi Identitas Budaya dalam Etika Berbahasa (Studi Kasus Masyarakat Bima). http://www.geogle. Com/search. 18 Desember 2018.

Rahmania, Annisa. 2009. Kata Sapaan dalam Masyarakat Baduy. Depok: Universitas Indonesia.

Rusbiyantoro, Wenni. 2011. Penggunaan Kata Sapaan dalam Bahasa Melayu Kutai. Parole Vol. 2 no. 1 April 2011.

Simajuntak, Mangantar. 1990. Teori-Teori Pemerolehan Fonologi. Jakarta: Gaya Media Pratama.

Tahir Alwi, Muhammad. 2003. Kamus Bima Indonesia Inggris. Bima: Kantor Bahasa Propinsi NTB.

Thomas, Linda dan Wareing, Shan. 2007. Bahasa, Masyarakat \& Kekuasaan. Yogyakarta: Pustaka Pelajar.

Wajdi, Majid. 2011. Reinterpretasi Teori Kata Sapaan dari Brown dan Gilman (1960): Analisis Penggunaan Stratifikasi Tuturan Bahasa Jawa. Bali: Politeknik Negeri Bali. 